\title{
Internal Control Weakness And Stock Price Crash Risk
}

Siwoon Hong, Sungkyunkwan University, South Korea

Jong Eun Lee, Sungkyunkwan University, South Korea

\begin{abstract}
Considering that stock price crashes are positively associated with opaque financial reporting and that effective internal control over financial reporting is essential for reliable and transparent financial reporting, it is thus vital to establish and maintain effective internal control over financial reporting. In this paper, we investigate the impact of internal control weakness on stock price crash risk, using the disclosures under Section 404 of the 2002 Sarbanes-Oxley Act. We find that material weakness in internal control over financial reporting increases information asymmetry by producing unreliable and/or opaque financial reporting, subsequently resulting in a stock price crash. Our study provides evidence that ineffective internal control over financial reporting is an indicator of future stock price crashes.
\end{abstract}

Keywords: Internal Control Weakness; Stock Price Crash; Information Asymmetry; Financial Reporting Transparency

\section{INTRODUCTION}

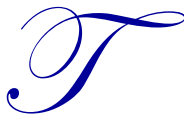

his study investigates the impact of internal control weakness on stock price crash risk, using the disclosures under Section 404(b) of the 2002 Sarbanes-Oxley Act.

Hutton et al. (2009) argue that hoarding bad news for long periods can lead to stock price crashes if the accumulated bad news is revealed all at once. They find a positive association between opaque financial reporting and stock price crash risk, suggesting that firms with lower financial transparency intentionally conceal bad news for a long time, increasing information asymmetry and eventually resulting in stock price crashes. Kim et al. (2011) find that tax avoidance leads to stock price crashes. We expand the literature (e.g., Hutton et al. 2009; Kim et al. 2011 2015) by examining if internal control weakness is another indicator of incoming stock price crashes.

It is well known that effective internal control over financial reporting (ICFR) is critical for producing reliable financial information. ${ }^{1}$ Effective ICFR enhances the reliability and accuracy of accounting information, thus reducing information risk. Firms with weak internal control are therefore more likely to withhold bad news and provide investors with less reliable financial information, which can increase information asymmetry.

We thus posit that ICFR effectiveness is negatively associated with stock price crash risk. Using sample firms that disclosed their ICFR effectiveness pursuant to SOX Section 404(b) from 2004 to 2012, we test how material weakness is associated with the occurrence of stock price crashes. ${ }^{2,3}$ We find that firms with ineffective

\footnotetext{
${ }^{1}$ AS No. 5 describes the importance of effective internal control over financial reporting as follows: "Effective internal control over financial reporting provides reasonable assurance regarding the reliability of financial reporting and the preparation of financial statements for external purposes. If one or more material weaknesses exist, the company's internal control over financial reporting cannot be considered effective."

${ }^{2}$ SOX Section 404(a) requires CEOs to evaluate and provide a management report on the effectiveness of their firms' ICFR annually. SOX Section 404(b) requires the firm's external auditor to issue an annual report with an opinion on the effectiveness of the client's ICFR based on an independent evaluation. SOX Section 404 has been effective for accelerated filers from the fiscal year beginning on or after November 15, 2004. Although non-accelerated filers have been required to comply with Section 404(a) from the fiscal year beginning on or after December 15, 2007,
} 
ICFR are more likely to suffer stock price crashes after controlling for the factors affecting them. Further analysis reveals that the more material weaknesses firms have, the more likely stock price crashes become.

Our study contributes to the research in several ways. First, the literature on internal control effectiveness has extensively investigated the economic consequence of internal control weakness. Our study provides additional evidence that ineffective internal control is positively associated with stock price crashes. Second, studies (e.g., Hutton et al. 2009) have revealed that stock price crash risk is positively (negatively) associated with opaque (transparent) financial information. Our finding of the positive association between internal control weakness and stock price crash risk confirms that effective ICFR plays a critical role in maintaining and/or enhancing the reliability of financial reporting and thus enhancing the transparency of financial information.

The rest of this paper is organized as follows. Section II provides a literature review and hypothesis development. Section III describes the research design, including the sample selection and measurement of crash risk and internal control weakness. Section IV presents our empirical results, and Section V concludes the paper.

\section{LITERATURE REVIEW AND HYPOTHESIS DEVELOPMENT}

Since the adoption of SOX Section 404, the economic consequences of disclosed internal control weaknesses have been extensively investigated. The literature documents a negative association between ineffective internal control and earnings quality. For instance, Doyle et al. (2007), Ogneva et al. (2007), and Chan et al. (2009) report that firms with material ICFR weaknesses have higher discretionary accruals. Moreover, markets negatively value the disclosure of internal control weaknesses under SOX Section 302 or 404 (e.g., Beneish et al., 2008; Hammersley et al., 2008; Ashbaugh-Skaife et al., 2009). Ashbaugh-Skaife et al. (2009) provide evidence that firms with internal control weaknesses are more likely to have higher costs of equity.

Hutton et al. (2009) show that opaque financial reporting is positively correlated with stock price crash risk. Kim et al. (2014) analyze the association between financial reporting transparency and stock price crashes in the context of firms' corporate social responsibility (CSR) activities. They find that more active CSR leads to enhanced financial reporting transparency, reducing the potential stock price crash risk. Kim et al. (2011) find that firms with higher sheltering probabilities, lower long-run cash effective tax rates, and larger book-tax differences are more likely to experience firm-specific stock price crashes. Consistent with the expectation that conservatism lowers stock price crash risk because conservative accounting releases bad news in a more timely way, Kim et al. (2015) find that conditional conservatism is significantly and negatively associated with stock price crash risk. Using a Chinese database, Xu et al. (2013) find that higher analyst coverage leads to stock price crash risk, a link that intensifies when analysts provide a more optimistic forecast to investors. Kim et al. (2014) provide evidence that stock price crashes are positively associated with managerial overconfidence.

Overall, then, the literature suggests that opaque financial reporting and/or information asymmetry is one of the most important factors affecting the occurrence of stock price crashes. Considering the positive association between effective ICFR and the reliability/transparency of financial reporting, therefore, we propose that internal control weakness can lead to stock price crash risk: Therefore, I hypothesize (at the alternative form):

H: Firms with ineffective internal control are more likely to have stock price crashes.

the Dodd-Frank Wall Street Reform and the 2010 Consumer Protection Act permanently exempted non-accelerated filers from Section 404(b) internal control audits (U.S. House of Representatives 2010).

${ }^{3}$ AS No. 5 defines "material weakness" as a "deficiency, or a combination of deficiencies, in internal control over financial reporting, such that there is a reasonable possibility that a material misstatement of the company's annual or interim financial statements will not be prevented or detected on a timely basis." 


\section{RESEARCH DESIGN}

\subsection{Empirical model}

We test our hypothesis through the following logistic regression:

$$
C R A S H_{i, t+l}=\alpha_{0}+\alpha_{1} M W_{i, t}+\alpha_{2} S I Z E_{i, t}+\alpha_{3} M B_{i, t}+\alpha_{4} L E V_{i, t}+\alpha_{5} R O E_{i, t}+\alpha_{6} D A_{i, t}+\varepsilon_{i, \tau}
$$

Following Hutton et al. (2009), we use the measure of stock price crash likelihood for each firm in each year $(C R A S H)$ in Eq. (1) as an indicator variable, equal to 1 if a firm experiences one or more crash weeks during a fiscal year period and 0 otherwise.

The measurement procedure for firm-specific crash risk is as follows. First, we estimate firm-specific weekly returns for each firm and year. The returns (W) are defined as the natural logarithm of one plus the residual return from the following expanded market model regression, following the literature (Jin and Myers, 2006):

$$
\begin{aligned}
& r_{j, \tau}=\alpha_{j}+\beta_{l j} r_{m, \tau-2}+\beta_{2 j} r_{m, \tau-1}+\beta_{3 j} r_{m, \tau}+\beta_{4 j} r_{m, \tau+1}+\beta_{5 j} r_{m, \tau+2}+\varepsilon_{j, \tau,} \\
& \mathrm{w}_{\mathrm{j}, \tau}=\ln \left(1+\varepsilon_{\mathrm{j}, \tau}\right)
\end{aligned}
$$

where $r_{j, \tau}$ is the return on stock $j$ in week $\tau$ and $r_{m, \tau}$ is the return in the CRSP value-weighted market index in week $\tau$. We include the lead and lag terms for the market index return to allow for nonsynchronous trading (Dimson, 1979). The firm-specific weekly return for firm $\mathrm{j}$ in week $\tau, \mathrm{w}_{\mathrm{j}, \tau}$, is calculated by Eq. (2). When estimating the firm-specific weekly return (W), we use residual return rather than raw return since the former can capture the firm-specific idiosyncratic factors.

We define "crash weeks" as those in which a firm experiences firm-specific weekly returns 3.2 standard deviations below the mean firm-specific weekly returns over the entire fiscal year. This number (3.2) is chosen to generate a frequency of $0.1 \%$ in the normal distribution.

The test variable, $M W(M W$ Dummy), is measured in two ways. First, $M W$ is a dummy variable equal to 1 if a firm discloses internal control weakness under SOX Section 404(b) and 0 otherwise. Second, $M W\left(M W_{-}\right.$Number) is measured as the number of internal control weaknesses disclosed. Following the literature (e.g., Hutton et al. 2009), we include control variables such as SIZE, $M B, L E V, R O E$, and $D A$. Firm size (SIZE) is a natural logarithm of the market value of equity at the beginning of the fiscal year. Market-to-book ratio $(M B)$ is the market value of equity scaled by the equity of book value at the beginning of the fiscal year. Leverage $(L E V)$ is the book value of total liabilities divided by total assets at the beginning of the fiscal year. Return on equity $(R O E)$ is the income before extraordinary items divided by the book value of equity. We also include discretionary accruals $(D A)$ to control for financial reporting transparency.

\subsection{Sample selection}

The initial sample concerning the effectiveness of internal control over financial reporting under SOX Section 404(b) comprises 18,264 firm-year observations covering 2004 to 2012, obtained from the Audit Analytics database. Stock return data for calculating stock price crash risk and financial statement data are obtained from the CRSP and Compustat fundamentals annual databases, respectively. The sample for internal control effectiveness is merged with the stock price crash variable and other control variables. Excluding missing variables and financial institutions (SIC code 6000-6999) produces 10,881 sample firms. 


\section{EMPIRICAL RESULTS}

\subsection{Descriptive Analysis and Univariate Analysis}

Table 1. Descriptive statistics

\begin{tabular}{lllrrrrr}
\hline \multicolumn{1}{c}{ Variable } & Mean & Median & Std. & Min & Q1 & Q3 & Max \\
\hline CRASH & 0.164 & 0.000 & 0.370 & 0.000 & 0.000 & 0.000 & 1.000 \\
MW_Dummy & 0.071 & 0.000 & 0.256 & 0.000 & 0.000 & 0.000 & 1.000 \\
MW_Number & 0.165 & 0.000 & 0.903 & 0.000 & 0.000 & 0.000 & 20.000 \\
SIZE & 7.036 & 6.885 & 1.758 & 0.561 & 5.710 & 8.141 & 13.131 \\
$M B$ & 2.849 & 2.135 & 3.606 & -15.284 & 1.409 & 3.340 & 32.909 \\
LEV & 0.510 & 0.496 & 0.289 & 0.014 & 0.332 & 0.647 & 6.883 \\
ROE & 0.051 & 0.105 & 0.512 & -6.044 & 0.025 & 0.179 & 4.177 \\
DA & 0.001 & 0.005 & 0.118 & -2.261 & -0.033 & 0.042 & 2.128 \\
\hline
\end{tabular}

Variable definitions: $M W$ Dummy is a dummy variable equal to 1 if a firm discloses internal control weaknesses under SOX Section 404(b) and 0 otherwise. MW_Number is measured as the number of disclosed internal control weaknesses. Firm size (SIZE) is a natural logarithm of the market value of equity at the beginning of the fiscal year. Market-to-book ratio $(M B)$ is the market value of equity scaled by the equity of book value at the beginning of the fiscal year. Leverage $(L E V)$ is the book value of total liabilities divided by total assets at the beginning of the fiscal year. Return on equity $(R O E)$ is the income before extraordinary items divided by the book value of equity. Discretionary accruals $(D A)$ are measured following Kothari et al. (2005).

Table 1 presents the descriptive statistics for the full sample $(\mathrm{n}=10,881)$. The results show that $16.4 \%$ $(\mathrm{n}=1,783)$ of the 10,881 sample firms suffer a stock price crash the following year. $7.1 \%(\mathrm{n}=773)$ of 10,881 sample firms disclose material weakness(es) in internal control over financial reporting. Each of SIZE, $M B$, and $L E V$ has a close mean and median. The mean values of $R O E$ and $D A$ are greater than the median values, indicating that $R O E$ and $D A$ are negatively skewed.

Table 2. Univariate Analysis

\begin{tabular}{|c|c|c|c|}
\hline & $C R A S H=1$ & $C R A S H=0$ & Difference in Mean \\
\hline & Mean & Mean & t-statistics \\
\hline MW_Dummy & 0.122 & 0.061 & $7.58^{* * *}$ \\
\hline$M W$ Number & 0.288 & 0.141 & $5.33^{* * *}$ \\
\hline$S I Z \bar{E}$ & 6.032 & 7.230 & $-32.22^{* * *}$ \\
\hline$M B$ & 2.931 & 2.833 & 0.85 \\
\hline$L E V$ & 0.527 & 0.507 & $2.04^{* *}$ \\
\hline$R O E$ & -0.118 & 0.084 & $-10.51^{* * *}$ \\
\hline$D A$ & -0.006 & 0.003 & $-2.13^{* *}$ \\
\hline 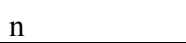 & 1,783 & 9,098 & \\
\hline
\end{tabular}

Table 2 presents the mean difference test results between stock price crash $(C R A S H=1)$ and non-stock crash firms $(C R A S H=0)$. Consistent with our expectation, $12.2 \%(n=218)$ of stock crash firms $(\mathrm{n}=1,783)$ have material ICFR weaknesses the year before the crash, compared to $6.1 \%(n=555)$ of non-stock crash firms $(n=9,098)$. The mean difference is significant at the $1 \%$ level, suggesting that weakness in internal control over financial reporting is more likely to cause stock price crashes. Moreover, the mean of $M W$ Number of stock price crash firms is significantly higher than that of non-stock crash firms. In addition, firms with stock price crashes are smaller, have higher leverage, are less profitable, and have more income-reducing discretionary accruals. Those mean differences are significant at the 1 or $5 \%$ level. 
Table 3. Correlation Analysis

\begin{tabular}{|c|c|c|c|c|c|c|c|c|}
\hline Variable & CRASH & MW_Dummy & MW_Number & $S I Z E$ & $M B$ & $L E V$ & $R O E$ & $D A$ \\
\hline$C R A S H$ & & $0.089 * * *$ & $0.061 * * *$ & $-0.253 * * *$ & 0.010 & $0.026^{* * *}$ & $-0.146 * * *$ & $-0.027 * * *$ \\
\hline MW_Dummy & $0.089 * * *$ & & $0.662 * * *$ & $-0.133 * * *$ & 0.001 & $0.038 * * *$ & $-0.037 * * *$ & -0.001 \\
\hline$M W_{-}$Number & $0.090 * * *$ & $0.999 * * *$ & & $-0.088 * * *$ & 0.001 & $0.069 * * *$ & $-0.022 * *$ & -0.004 \\
\hline$S I Z \bar{E}$ & $-0.259 * * *$ & $-0.141 * * *$ & $-0.141 * * *$ & & $0.159 * *$ & $0.100 * * *$ & $0.168 * * *$ & -0.012 \\
\hline$M B$ & $-0.033 * * *$ & $-0.029 * * *$ & $-0.029 * * *$ & $0.327 * * *$ & & $-0.068 * * *$ & $0.089 * * *$ & -0.003 \\
\hline$L E V$ & $-0.016^{*}$ & $0.019 * *$ & $0.021 * *$ & $0.224 * * *$ & $-0.039 * * *$ & & $0.071 * * *$ & $0.018^{*}$ \\
\hline$R O E$ & -0.18 & $-0.100 * * *$ & $-0.102 * * *$ & $0.373 * * *$ & $0.433 * * *$ & $0.183 * * *$ & & $0.156 * * *$ \\
\hline$D A$ & $-0.030 * * *$ & -0.004 & -0.003 & $-0.024 * *$ & $0.062 * * *$ & -0.003 & $0.167 * * *$ & \\
\hline
\end{tabular}

The numbers above (below) the diagonal are the Pearson (Spearman) correlation coefficients, and $* * *, * *$, and $*$ denote statistical significance at the 1,5 , and $10 \%$ level, respectively.

See Table 1 for variable definitions.

Table 3 reports the correlation between all the variables used in the empirical model. As expected, $C R A S H$, $M W \_$Dummy, and $M W \_$Number are positively and significantly correlated, offering preliminary evidence that firms with material weaknesses in their internal control over financial reporting are more likely to have a stock price crash the following year. CRASH is negatively correlated with SIZE. All correlations are below 0.5 , except for that between $M W_{-}$Dummy and $M W_{-}$Number.

\subsection{Multivariate Analysis}

Table 4 provides the regression results of the association between material weakness in internal control over financial reporting and stock price crashes. Model (1) in Table 4 shows the result, using the dummy variable $M W_{-}$Dummy as a test variable. The coefficient (0.373) of $M W_{-}$Dummy is positive and significant at the $1 \%$ level, suggesting that firms with weak ICFR are more likely to have a stock price crash the following year. This result persists when $M W$ Number is used as an alternative test variable in Model (2). Here, the coefficient (0.067) of $M W \_$Number is significant at the $1 \%$ level. Our hypothesis is thus strongly supported by the empirical results.

Table 4. Results Of Logistic Regressions

\begin{tabular}{|c|c|c|c|c|}
\hline \multirow[b]{2}{*}{ Variable } & \multicolumn{2}{|c|}{$\begin{array}{c}\text { DV }=\text { CRASH } \\
\text { (1) }\end{array}$} & \multicolumn{2}{|c|}{$\begin{array}{c}\text { DV }=\text { CRASH } \\
\text { (2) }\end{array}$} \\
\hline & Coefficient & t-statistics & Coefficient & t-statistics \\
\hline Intercept & -0.568 & -0.02 & -0.510 & -0.02 \\
\hline MW_Dummy & $0.373^{* * *}$ & 3.94 & & \\
\hline MW Number & & & $0.067^{* * *}$ & 2.63 \\
\hline$S I Z \bar{E}$ & $-0.489^{* * *}$ & -23.75 & $-0.494^{* * *}$ & -24.13 \\
\hline$M B$ & $0.037^{* * *}$ & 5.10 & $0.037^{* * *}$ & 5.06 \\
\hline$L E V$ & $0.718^{* * *}$ & 7.26 & $0.719^{* * *}$ & 7.26 \\
\hline$R O E$ & $-0.423^{* * *}$ & -8.85 & $-0.424^{* * *}$ & -8.89 \\
\hline$D A$ & -0.309 & 1.53 & -0.307 & -1.53 \\
\hline$Y E A R$ & \multicolumn{2}{|c|}{ Included } & \multicolumn{2}{|c|}{ Included } \\
\hline$I N D$ & \multicolumn{2}{|c|}{ Included } & \multicolumn{2}{|c|}{ Included } \\
\hline Max-rescaled $\mathrm{R}^{2}$ & \multicolumn{2}{|c|}{$20.51 \%$} & \multicolumn{2}{|c|}{$20.39 \%$} \\
\hline $\mathrm{n}$ & \multicolumn{2}{|c|}{10,881} & \multicolumn{2}{|c|}{10,881} \\
\hline
\end{tabular}

Note:***,**, and $*$ denote statistical significance at the 1,5 , and $10 \%$ level, respectively (two-tailed test).

See Table 1 for variable definitions.

Overall, consistent with our expectation, we find that ineffective ICFR is positively associated with stock price crash risk, suggesting that internal control deficiency is an indicator of stock price crashes.

\section{SUMMARY AND CONCLUSIONS}

As is well known, opaque financial reporting is more likely to cause information asymmetry, leading to stock price crashes. Establishing and maintaining effective internal control over financial reporting is essential for reliability and transparency. 
This paper examines the association between weak internal control and the occurrence of stock price crashes, finding that material ICFR weakness increases information asymmetry by producing unreliable and/or opaque financial reporting, resulting in stock price crashes. Our study thus provides evidence that weak ICFR is an indicator of stock price crashes.

\section{AUTHOR INFORMATION}

Siwoon Hong is a Ph.D. student of accounting at Business School, SungKyunKwan University, South Korea. Prior to joining the Ph.D. program, she worked at a tax office as a certified tax accountant. Her research areas include tax subsidy, earnings management, and internal control. E-mail:dbayd@skku.edu.

Jong Eun Lee(Corresponding author) is an associate professor at Business School, SungKyunKwan University, South Korea. He received his Ph.D. from Temple University. His research areas include audit quality, internal control, and corporate governance. E-mail:jelee2012@skku.edu.

\section{REFERENCES}

Ashbaugh-Skaife, H., D. Collins and W. Kinney. 2007. The Discovery and Reporting of Internal Control Deficiencies Prior to SOX-mandated Audits. Journal of Accounting and Economics 44: 166-192.

Ashbaugh-Skaife, H., D. Collins, W. Kinney and R. LaFond. 2008. The Effects of SOX Internal Control Deficiencies and their Remediation on Accrual Quality. The Accounting Review 83: 217-250.

Beneish, M. D., M. B. Billings and L. D. Hodder. 2008. Internal Control Weaknesses and Information Uncertainty. The Accounting Review 83: 665-703.

Dimson, E. 1979. Risk measurement when shares are subject to infrequent trading. Journal of Financial Economics 7: 197-226.

Doyle, J., W. Ge and S. McVay. 2007. Accrual Quality and Internal Control over Financial Reporting. The Accounting Review 82:1141-1170.

Hammersley, J. S., L. A. Myers and C. Shakespeare. 2008. Market Reactions to the Disclosure of Internal Control Weaknesses and to the Characteristics of those Weaknesses under Section 302 of the Sarbanes-Oxley Act of 2002. Review of Accounting Studies 14: 401-439.

Hutton, A. P., A. J. Marcus, and H. Tehranian. 2009. Opaque financial reports, ${ }^{2}$, and crash risk. Journal of Financial Economics 94: 67-86.

Jin, L., and S. C. Myers. 2006. $\mathrm{R}^{2}$ around the world: New theory and new tests. Journal of Financial Economics 79 : 257-292.

Kim, J-B., Y. Li, and L. Zhang. 2011. Corporate tax avoidance and stock price crash risk: Firm-level analysis. Journal of Financial Economics 100: 639-662.

Kim, J-B., and L. Zhang. 2015. Accounting conservatism and stock price crash risk: Firm-level evidence. Contemporary Accounting Research, Forthcoming.

Kim, J-B, Z. Wang, and L. Zhang. 2014. CEO Overconfidence and Stock Price Crash Risk. Available at: http://ssrn.com/abstract $=2331189$

Kim, Y., H. Li, and S. Li. 2014. Corporate social responsibility and stock price crash risk. Journal of Banking \& Finance 43: 1-13.

Kothari, S. P., A. J. Leone, C. E. Wasley. 2005. Performance Matched Discretionary Accrual Measures, Journal of Accounting and Economics 39(1): 163-197.

Public Company Accounting Oversight Board (PCAOB). 2007. An Audit of Internal Control over Financial Reporting that is Integrated with an Audit of Financial Statements. Auditing Standard No. 5. Washington D.C.: PCAOB.

U.S. House of Representatives. 2010 Dodd-Frank Wall Street Reform and Consumer Protection Act. Public Law 111-203 [H. R. 4173], Washington, D.C.: Government Printing Office.

Xu, N., X. Jiang, K. C. Chan, Z. Yi. 2013. Analyst coverage, optimism, and stock price crash risk: Evidence from China. Pacific-Basin Finance Journal 25: 217-239. 